\title{
Aspek-Aspek Nilai Kebahasaan Jihad Dalam Pandangan Al-Qur,an
}

\author{
Bunyamin \\ Dosen IAIN Watampone \\ Email alyamin2009@gmail.com
}

\begin{abstract}
The interpretation of the verses of jihad, a few theories were found. First, ontologically, jihad can be divided into general and specific meaning. Generally speaking, jihad is all activities undertaken in earnest to uphold the good and resist damage in the midst of society. Meanwhile, in particular, jihad is a seriousness to defend the establishment of Islamic teachings on the battlefield. Second, epistemologically, the forms of jiha d can be divided into jihad amwal and jihad anfus. Jihad amwal is the sacrifice of property to the maximum, both in connection with jihad in general or specifically. While jihad anfus is totality of the human soul is a sacrifice to defend the teachings of Islam, both in relation to jihad jihad in general or specifically. Third, axiologically, the implications of jihad can be distinguished on worldly and hereafter interests. In earthly life, the mujahid will always be guided by God for the right path and rewarded in kind, such as recognition, power, peace, and abundant sustenance.
\end{abstract}

Kata Kunci: al-Qur'an dan jihad.

\section{Pendahuluan}

Ayat-ayat jihad merupakan salah satu di antara muatan Alquran yang menimbulkan pemahaman kontroversial, baik secara internal maupun eksternal. Secara internal, terdapat kelompok umat Islam yang memahami ayat-ayat jihad sebagai dasar pembenaran melakukan pembunuhan terhadap orang-orang kafir. Dengan pemahaman itu, mereka berani melakukan aksi bom bunuh diri untuk menghancurkan sasaran kegiatan orang-orang kafir. ${ }^{1}$ Bahkan, mereka menganggap bahwa pelaku bom bunuh diri tersebut sebagai syahid (pejuang yang mati di jalan Allah).

${ }^{1}$ http://id.wikipedia.org/wiki/ Terorisme_di_Indonesia, 2012. 
Adapun secara eksternal, banyak dari kalangan non-Islam, khususnya orang-orang Barat, memandang bahwa melalui doktrin jihad, Alquran melegalisasi terorisme. Sebagai contoh, film Fitna yang ditayangkan di internet oleh Geert Wilders, seorang politisi Belanda, dengan durasi lebih dari 16 (enam belas) menit, memuat rangkaian video yang diyakininya sebagai ayat-ayat Alquran yang fasis, muslim yang bengis dan haus darah. Bahkan, sebagian non-Islam menuduh bahwa, melalui doktrin jihad, ajaran Islam disebarkan dengan kekerasan dan pedang. Tuduhan seperti ini, antara lain dilontarkan oleh Paus Paulus XVI. ${ }^{2}$

Jika ditelusuri kitab-kitab yang ada, ditemukan bahwa sebagian mufassir dalam mengelaborasi ayat-ayat jihad, masih bertumpu pada penafsiran tekstual, tanpa memperhatikan data-data sejarah. Misalnya, Ibn Katsir, ketika menafsirkan QS. al-Furqan/25/42: 52, memaknai kata jihad dengan perlawanan keras terhadap orang-orang kafir, sehingga frasa jihad dan kabira dihu-bungkan dengan QS. al-Taubah/9/113: 73 yang memerintahkan kepada Rasulullah saw. untuk bersikap keras terhadap orang-orang kafir dan orang-orang munafik. ${ }^{3}$ Bahkan, al-Mawardi, ke-tika menafsirkan frasa jihad al-kabira dalam QS. al-Furqan/25/42: 52, menyebut dua bentuk jihad dalam menghadapi orang-orang kafir, yaitu pedang dan kekerasan. ${ }^{4}$

M. Galib Mattola mengatakan bahwa istilah jihad tidak selalu berkonotasi perang fisik, sebab terdapat beberapa ayat yang berbicara tentang jihad, tetapi tidak berkonotasi perang, khu-susnya ayat-ayat al-makkiyyah, seperti QS. al-'Ankabut/29/ 85: 6 dan 69.5 Kedua ayat tersebut memberikan indikasi bahwa jihad yang dimaksudkan adalah mencurahkan seluruh kemam-puan yang dimiliki untuk mencapai ridha Allah. Karena itu, orang yang berjihad di jalan Allah tidak mengenal putus asa, menyerah, atau berkeluh kesah.

\section{Metode}

Dalam mengumpulkan data yang diperlukan dalam kajian ini, penulis menggunakan metode library research (penelitian kepustakaan). Sebagai wujud dari metode ini, penulis meng-gunakan Alquran dan buku-buku tafsir sebagai rujukan primer. Di samping itu, digunakan pula buku-buku lain yang sesuai dengan pembahasan ini sebagai sumber sekunder. Selanjutnya, data yang diperoleh dari kepustakaan tersebut dianalisis secara deskriptif kualitatif. Teknik analisis ini memberi gambaran ten-tang alur logika analisis data, sekaligus memberi masukan ter-hadap teknik analisis data kualitatif yang digunakan. ${ }^{6}$

${ }^{2}$ http://matabaca.multiply.com/journal/item/6, 2010.

3al-Dimasyqi, Abu al-Fida' Isma'il ibn 'Umar ibn Kastir al-Qurasyi. Tafsir al-Qur'an al-'Az\}im, dalam Program CD al-Maktabah al-Syamilah, versi 2.11, http://www.shamela.ws. th. h. 116.

${ }^{4}$ al-Mawardi, Abu al-Hasan 'Ali ibn Muhłammad ibn Muh\}ammad ibn Habib al-Basri al-Bagdadi alNukat wa al-'Uyun, dalam Program CD al-Maktabah al-Syamilah, versi 2.11, http://www. shamela. ws, tth. h. 205.

${ }^{5}$ M. Galib Mattola (http://www.psq.or.id/ensiklo pedia.. asp? $\left.\mathrm{mnid}=34 \& i d=60,2009\right)$.

${ }^{6}$ Lexy J. Moleong, Metodologi Penelitian Kualitatif, (Cet. X; Bandung: PT Remaja Rosdakarya, 1999), h. 3. 
Dalam mengolah data yang berupa ayat-ayat Alquran, penulis menggunakan teknik interpretasi linguistik, sistemik, his-toris, filosofis, dan eksegisis. Interpretasi pertama adalah upaya penerapan kaidah-kaidah kebahasaan, baik dari segi semantik etimologis, semantik morfologis, maupun semantik leksikal. Inter-pretasi kedua adalah upaya memahami relevansi antara yang satu dengan ayat lainnya yang berkenaan dengan jihad. Interpretasi ketiga adalah upaya memahami konteks sosiologis dan historis ayat yang dibahas. Interpretasi keempat adalah upaya meng-klasifikasi ayatayat kenabian dengan mengikuti pola pikir filsafat ilmu. Sedangkan interpretasi yang disebut terakhir adalah upaya menggali kandungan ayat-ayat kenabian dengan mengacu pada kitab-kitab tafsir.

\section{Hasil}

\section{Pengertian Jihad}

Dari segi historical language, al-Qasimi menegaskan bahwa jihad merupakan istilah khusus yang digunakan setelah kedatangan agama Islam dan belum dikenal pada masa jahiliah, sebab istilah tersebut tidak ditemukan dalam syair-syair jahiliah, baik yang semakna maupun yang menyerupainya. Jihad merupakan istilah khusus yang digunakan dalam agama Islam, sebagaimana halnya dengan istilah salat dan zakat yang memiliki makna khusus, tidak serupa dengan makna istilah lainnya.

Menurut Ibn Faris, kata jihad berakar pada huruf jin, ha, dan dal, yang arti asalnya adalah almasyaqqah (kesulitan), kemudian dialihkan kepada makna yang mirip dengannya. ${ }^{7}$ Dari akar kata yang sama, terbentuk pula kata ijtihad, dengan meng-ikuti pola timbangan ifti 'al, yang menurut alQardawi, menunjukkan arti berarti berlebih (mubalagah) dalam melaksanakan suatu per-buatan. ${ }^{8}$ Arti ini menunjukkan bahwa jihad dan ijtihad tidak terlepas dari kesulitan, kemampuan, dan kesungguhan dalam sebuah aktivitas.

Kata jihad dalam berbagai bentuknya, terulang sebanyak 41 (empat puluh satu) kali dalam Alquran. Dari pengulangan ter-sebut, ditemukan beberapa pola kata yang terpakai: (1) jahda/juhda yang berarti usaha keras dan kesanggupan, antara lain ditemukan dalam QS Fatir/35/43: 42, QS alNahl/16/70: 38, QS al-Nur/24/102: 53, dan QS al-Ma'idah/5/112: 53; (2) jahada/ yujahidu/jihad yang berarti usaha keras dan perjuangan di medan perang, antara lain ditemukan dalam QS Luqman/31/57: 15, QS al-'Ankabut/29/85: 8, dan QS al-Taubah/9/113: 73; serta (3) almujahidun/al-mujahidin yang berarti orang-orang yang berjuang di medan perang. Antara lain terdapat dalam QS al-Nisa'/4/92-95.

${ }^{7}$ Abi al-Husain Ahmad ibn Faris Ibn Zakariyyah, Mu'jam al-Maqa-yis fi al-Lugah, (Cet. II; Barut: Dar alFikr li al-Taba'ah wa al-Nasyr wa al-Tauzi', 1998). h. 227.

${ }^{8}$ Al-Qardawi, Yusuf. Al-Ijtihad fi al-Syari'ah al-Islamiyyah ma'a Naz-arat Tahliliyyah fi al-Ijtihad al-Mu'as\}ir, terj. Ahmad Syathori, Ijtihad dalam Syari'at Islam: Analisis terhadap Ijtihad Kontemporer (Cet. I: Jakarta: Bulan Bintang, 1987), h. 47-48. 
Dari keragaman pola bentukan kata jim-ha-dal yang terpakai dalam Alquran, dapat dipahami bahwa kata jihad dalam Alquran memiliki makna dan ruang lingkup yang luas, yaitu bersungguhsungguh, berusaha dengan keras, memiliki kesanggupan, dan berjuang di medan perang. Arti-arti ini saling terkait antara satu dengan lainnya. Para mujahid senantiasa bersungguh-sungguh dan berusaha keras dalam perjuangannya untuk membela agama Allah, sesuai dengan kemampuannya masing-masing. Jika ada mampu berjihad dengan harta, pikiran, dan fisik sekaligus, maka itulah jihad yang tertinggi. Namun, jika tidak sanggup, maka dia bisa berjihad dengan hartanya, atau pikirannya, atau pun fisiknya saja.

\section{Bentuk-Bentuk Jihad}

Jika ditelusuri semua ayat jihad yang terdapat dalam Alquran, ditemukan sembilan ayat yang berkenaan dengan ben-tuk-bentuk jihad, yang secara keseluruhan berada dalam kelom-pok surahsurah al-madaniyyah. Kedelapan ayat yang dimaksud, masing-masing QS al-Anfal/8/88: 72, QS alNisa'/4/92: 95, QS al-Hujurat/49/106: 15, QS al-Ṣaff/61/109: 11, QS al-Taubah/9/113: 20, QS alTaubah/9/113: 41, QS al-Taubah/9/113: 44, QS al-Taubah/9/113: 81, dan QS al-Taubah/9/113: 88. Hasil analisis ayat-ayat tersebut menunjukkan dua bentuk jihad, yaitu amwal dan anfus. Ada tiga teori yang ditemukan dalam penggunaan kedua term tersebut.

Pertama, penggunaan kedua term itu senantiasa dalam ben-tuk plural (amwal dan anfus), menunjukkan bahwa setiap umat Islam yang ingin berjihad, hendaklah jihadnya itu dilakukan secara maksimal, yakni tidak tanggung-tanggung dalam mengor-bankan harta bendanya dan atau bersedia melakukan pengor-banan jiwa secara menyeluruh. Hal ini telah dicontohkan oleh Rasulullah saw. bersama kaum muhajirin dan ansar, sebagaimana yang diabadikan dalam QS alAnfal/8/88: 72 sebagai berikut:

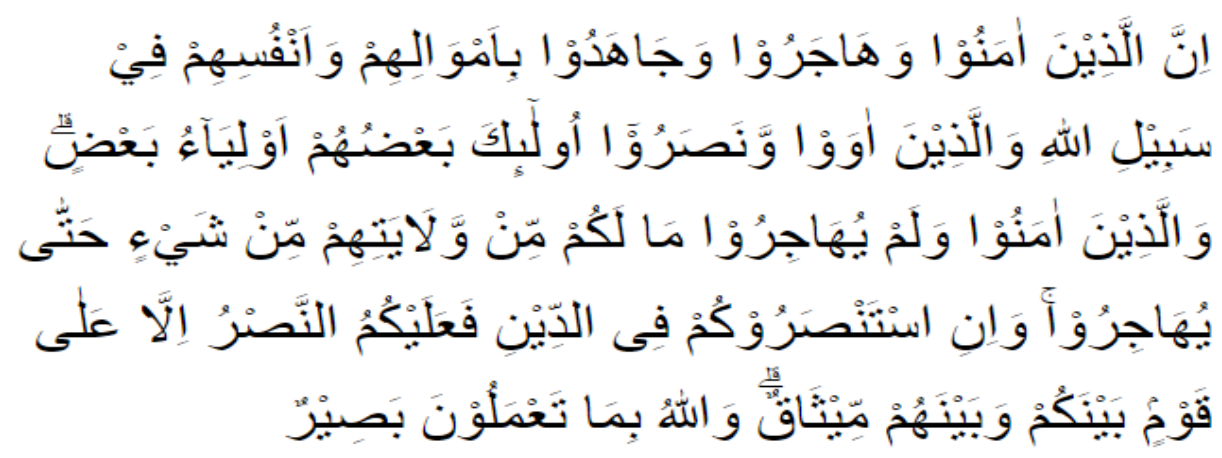

Terjemahnya:

Sesungguhnya orang-orang yang beriman dan berhijrah serta berjihad dengan harta dan jiwanya pada jalan Allah dan orang-orang yang memberikan tempat kediaman dan pertolongan (kepada orang-orang muhajirin), mereka itu satu sama lainnya lindung-melindungi. Dan (terhadap) 
orang-orang yang beriman, tetapi belum berhijrah, maka tidak ada kewajiban sedikitpun atasmu melindungi mereka, sebelum mereka berhijrah. (Akan tetapi) jika mereka meminta pertolongan kepadamu dalam (urusan pembelaan) agama, maka kamu wajib memberikan pertolongan kecuali terhadap kaum yang telah ada perjanjian antara kamu dengan mereka. Dan Allah Maha Melihat apa yang kamu kerjakan.

Dalam menafsirkan QS al-Anfal/8/88: 72-75, al-Maragii mengklasifikasi umat Islam atas empat kelompok: (1) kaum muhajirin pertama, yaitu orang-orang yang ikut hijrah bersama Rasulullah sebelum perang Badar sampai masa perjanjian Hudai-biyyah, (2) kaum anshar, yaitu orang-orang Madinah yang mem-berikan tempat kepada Rasulullah dan kaum muhajirin ketika berhijrah, (3) orang-orang mukmin yang belum berhijrah, dan (4) orang-orang mukmin yang berhijrah setelah perjanjian Hudaibiyyah. ${ }^{9}$

Kedua, penyebutan kedua term terbahas (amwal dan anfus) senantiasa secara beriringan, atau dengan kata lain, tidak pernah disebut secara terpisah, menunjukkan orang-orang yang berjihad dengan harta dan jiwa sekaligus adalah termasuk dalam golongan orang-orang yang sempurna keimanannya. Orang-orang seperti itu telah digambarkan dalam QS. al-Hujurat/49/106: 15 sebagai berikut:

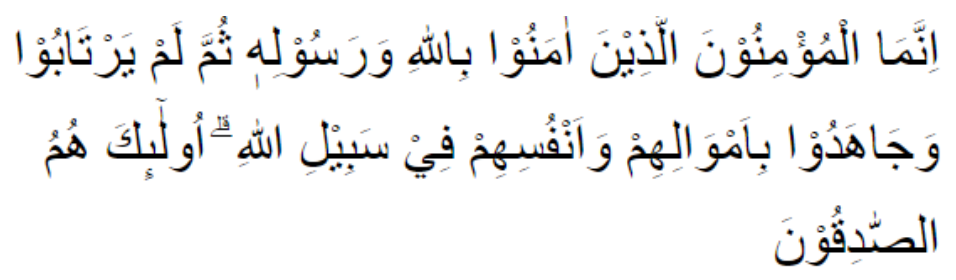

Terjemahnya:

Sesungguhnya orang-orang yang beriman hanyalah orang-orang yang beriman kepada Allah dan Rasul-Nya kemudian mereka tidak ragu-ragu dan mereka berjihad dengan harta dan jiwa mereka pada jalan Allah, mereka itulah orang-orang yang benar.

Al-Maragi mengemukakan bahwa sesungguhnya orang-orang yang beriman dengan iman yang sebenarnya adalah orang-orang yang membenarkan Allah dan Rasul-Nya, tidak ragu-ragu dan tidak goncang, bahkan mereka mantap pada satu sikap dan mau mengorbankan jiwa dan harta benda mereka yang paling mahal, demi ketaatan kepada Allah dan mengharapkan rida-Nya. Mereka itulah orang-orang yang benar dalam mengatakan amanna (kami beriman). Bukan seperti sebagian orang Badui yang iman mereka hanyalah kata-kata yang lahir saja, sedang mereka masuk agama Islam hanya karena takut terhadap pedang, supaya darah dan harta mereka terpelihara. ${ }^{10}$

${ }^{9}$ Ahmad Mustafa al-Maragi, Tafsir al-Maragi, (Bairut: Dar al-Fikr li al-Taba'ah wa al-Nasyr wa al-Tauzi', t.th.), h. 41.

${ }^{10}$ Ahmad Mustafa al-Maragi, op. cit. h. 147. 
Gambaran orang-orang yang sempurna keimanannya, juga ditegaskan dalam QS alSaff/61/109: 11 yang berbunyi:

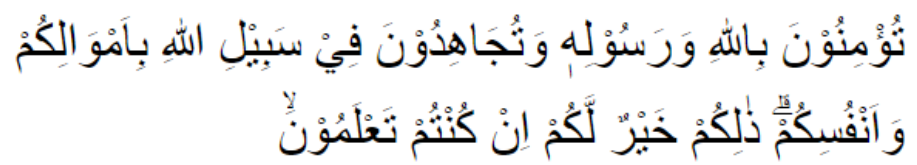

Terjemahnya:

(yaitu) kamu beriman kepada Allah dan Rasul-Nya dan berjihad di jalan Allah dengan harta dan jiwamu. Itulah yang lebih baik bagi kamu jika kamu mengetahuinya.

Dalam menafsirkan ayat di atas, Hamka mengatakan bahwa sesudah iman kepada Allah dan Rasul-Nya mantap, hendaklah dibuktikan dengan kesanggupan dan keinginan berjihad di jalan Allah, yakni bekerja keras, berjuang, tidak kenal menyerah, tidak kenal berhenti, apalagi mundur dalam menegakkan jalan Allah. Harta benda dikorbankan untuk perjuangan itu. Bukan harta saja, tetapi jiwa pun perlu dikorbankan untuk menegakkan agama Allah. ${ }^{11}$

Bagi mereka yang sudah sempurna keimanannya tersebut, tidak akan meminta izin untuk tidak ikut berjihad di medan perang. Hal ini digambarkan dalam QS. al-Taubah/9/113: 44 sebagai berikut:

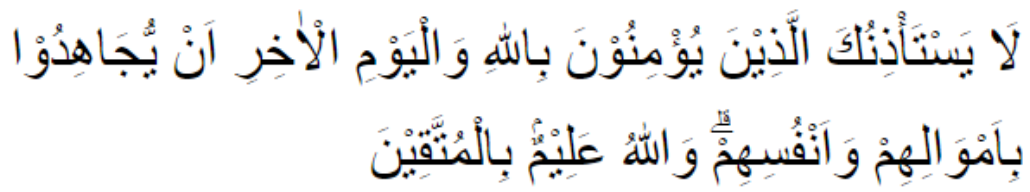

Terjemahnya:

Orang-orang yang beriman kepada Allah dan hari Kemudian, tidak akan meminta izin kepadamu untuk tidak ikut berjihad dengan harta dan diri mereka. dan Allah mengetahui orang-orang yang bertakwa.

Kondisi orang-orang munafik sangat bertolak belakang dengan orang-orang mukmin. Orang-orang munafik tersebut bukan hanya tidak ikut berjihad di medan perang, bahkan mereka memprovokasi orang lain agar tidak ikut bersama Rasulullah saw. Hal ini dijelaskan dalam QS. al-Taubah/9/113: 81:

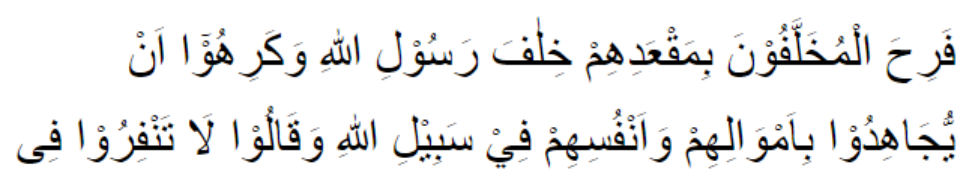

11Hamka Hamka, Tafsir al-Azhar, (Cet. III; Jakarta: Panji Masyara-kat, 1982), h. 190. 


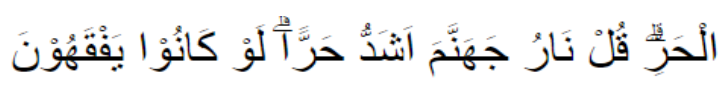

Terjemahnya:

Orang-orang yang ditinggalkan (tidak ikut berperang) itu, merasa gembira dengan tinggalnya mereka di belakang Rasulullah, dan mereka tidak suka berjihad dengan harta dan jiwa mereka pada jalan Allah dan mereka berkata: "Janganlah kamu berangkat (pergi berperang) dalam panas terik ini". Katakanlah: "Api neraka Jahannam itu lebih sangat panas-(nya)", jikalau mereka mengetahui.

Ayat di atas membiacarakan tentang keadaan orang-orang munafik yang bergembira karena tidak ikut memikul kewajiban yang diperintahkan kepada mereka, yakni berperang di bawah pimpinan Rasulullah. Mereka gembira karena tidak mengor-bankan harta benda dan jiwa mereka di jalan Allah. Selain itu, mereka pun memprovokasi orang lain agar tidak ikut pula berperang, dengan alasan bahwa suasana padang pasir sangatlah panas. Alangkah rusaknya jiwa mereka itu karena bergembira di tengah penderitaan Rasulullah bersama pasukannya dalam menghadapi tentara Romawi yang hendak menyerbu Madinah di tengah musim panas. Kegembiraan mereka itu tidak bernilai jika dibandingkan dengan kegembiraan yang dialami para pasukan yang kembali dengan selamat atau pasukan yang syahid di medan perang. ${ }^{12}$

QS al-Nisa'/4/92: 95 menjelaskan tentang perbedaan derajat antara orang-orang yang ikut berjihad di Medan perang dengan orang-orang yang hanya duduk di rumah mereka.

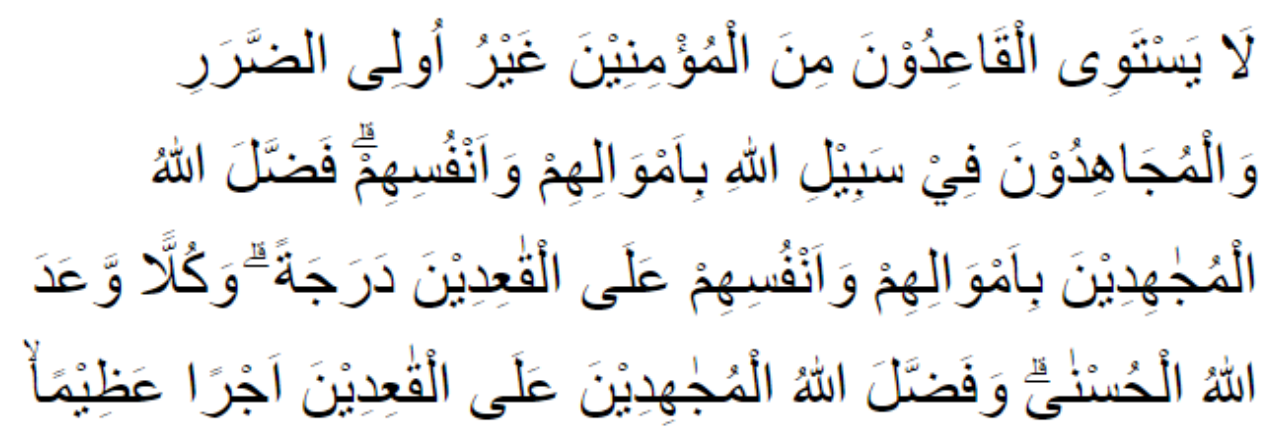

Terjemahnya:

Tidaklah sama antara mu'min yang duduk (yang tidak turut berperang) yang tidak mempunyai 'uzur dengan orang-orang yang berjihad di jalan Allah dengan harta mereka dan jiwanya. Allah melebihkan orang-orang yang berjihad dengan harta dan jiwanya atas orang-orang yang duduk satu derajat. Kepada masing-masing mereka Allah menjanjikan pahala yang baik (syurga) dan Allah melebihkan orang-orang yang berjihad atas orang yang duduk dengan pahala yang besar.

Kata al-qa'idun (yang duduk) dalam ayat di atas diperhadapkan dengan kata al-mujahidun (para pejuang), padahal biasanya "duduk" diperhadapkan dengan "berdiri". Hal ini menunjukkan bahwa

12Hamka, op. cit., h. 305. 
orang-orang mukmin di masa awal senantiasa bersiap memenuhi panggilan berperang, tak satu pun di antara mereka yang bermalas-malasan. ${ }^{13}$ Artinya, orang-orang yang duduk dianalogikan sebagai orang yang tidak siap berperang. Orang-orang seperti itu tidak dapat disebut sebagai mukmin sejati, bahkan QS. al-Taubah/9/113: 81 menyebutkan bahwa yang memiliki sifat seperti itu hanyalah orang-orang munafik.

Ketiga, term amwal senantiasa disebut lebih awal daripada term anfus dan tidak pernah disebut secara terbalik, menunjukkan tentang pentingnya menyumbangkan harta benda bagi umat Islam yang mampu, meski ia terlibat secara fisik dalam per-tempuran. Hal ini sangat terkait dengan kondisi pasukan Islam yang sangat membutuhkan bantuan dana yang besar dalam berbagai pertempuran yang dihadapi Rasulullah saw. bersama para sahabatnya.

Mengacu pada interpretasi beberapa ayat yang telah dikemukakan di atas, maka berikut ini dapat dirumuskan dua bentuk jihad yang dipahami dalam Alquran, yaitu:

\section{Jihad Amwal}

Kata amwal adalah bentuk plural dari kata mal, tersusun dari huruf mim, ya, dan lam yang bermakna dasar "terjadinya kecen-derungan pada sesuatu yang ada di sekitarnya". ${ }^{14}$ Arti ini menunjukkan bahwa harta memiliki daya tarik, sehingga semua manusia cenderung memilikinya.

Dalam berbagai bentuknya, kata ini terulang sebanyak 86 kali dalam Alquran. Dari pengulangan ini, 25 kali di antaranya dalam bentuk tunggal (mal), misalnya QS. al-An'am/6/55: 152. Sementara itu, 61 kali terulang dalam bentuk plural (amwal), misalnya QS. al-Taubah/9/113: 34. Dari jumlah ini, yang terbanyak dibicarakan adalah harta dalam bentuk obyek. Hal ini memberi kesan bahwa harta merupakan obyek kegiatan manusia dalam aktivitas kesehariannya. ${ }^{15}$

Penggunaan bentuk plural (amwal) dalam hubungannya dengan jihad, menunjukkan bahwa segala bentuk perjuangan untuk membela agama Allah, dibutuhkan biaya yang besar, se-hingga umat Islam tidak boleh tanggung-tanggung dalam mengorbankan hartanya, demi tegaknya agama Allah di muka bumi ini.

Dalam kaitannya dengan kewajiban berjihad dengan harta, Takruri menegaskan bahwa, setiap umat Islam wajib berjihad dengan hartanya, sesuai dengan kadar kemampuannya. Kewa-jiban ini berlaku bagi laki-laki maupun wanita, dewasa maupun anak-anak, dan kaya maupun miskin. Pendapat ini sangat tepat jika dihubungkan dengan pengertian jihad dalam arti umum, bukan dalam arti khusus. ${ }^{16}$

\section{Jihad Anfus}

${ }^{13}$ M. Quraish Shihab, Tafsir al-Mishbah: Pesan, Kesan dan Keserasian al-Qur'an, (Cet. X; Tangerang: Lentera Hati, 2008), h. 560.

${ }^{14}$ Abi al-Husain Ahmad ibn Faris Ibn Zakariyyah, op. cit., h. 971.

${ }^{15}$ M. Quraish Shihab, op. cit., h. 405-406.

16Ibid., h. 79. 
Kata anfus, bentuk pural dari kata nafs, tersusun dari huruf nun, fa, dan sin yang arti asalnya adalah keluarnya udara sebagaimana biasanya, misalnya angin dan semacamnya. ${ }^{17}$ Kata nafs dalam bentuknya, terulang sebanyak 295 kali dalam Alquran. Dari pengulangan tersebut, terkadang berarti jiwa (QS. al-Ma'idah/5/112: 32), nafsu (QS. al-Fajr/89/10: 27), atau nyawa (QS. alAnkabut/29/85: 57). Menurut M. Quraish Shihab, Alquran mempersonifikasikan wujud seseorang di hadapan Allah dan masyarakat dengan menggunakan kata nafs, sehingga kata tersebut dapat dipahami sebagai totalitas manusia, yang men-cakup nyawa, emosi, pengetahuan, tenaga, pikiran, bahkan waktu dan tempat, sebab manusia tidak dapat melepaskan diri dari waktu dan tempat. ${ }^{18}$

Penggunaan bentuk plural (anfus) pada semua ayat jihad, menunjukkan bahwa segala bentuk perjuangan untuk membela agama Allah, dibutuhkan pengorbanan jiwa secara menyeluruh; rela bekerja keras, rela mengorbankan nyawa sendiri, dan rela berpisah dengan orang-orang yang disayangi (istri, anak, dan keluarga terdekat), demi tegaknya agama Allah di muka bumi ini. Dengan demikian, mujahid adalah orang yang mencurahkan seluruh kemampuannya atau rela berkorban dengan semua yang berkaitan dengan dirinya sendiri.

Sebagaimana halnya dengan jihad al-mal, jihad al-nafs juga dapat dibedakan atas makna umum dan khusus. Dalam penger-tiannya yang umum, jihad nafs adalah mencurahkan segala potensi yang ada pada diri seseorang dalam menegakkan kebenaran dan keadilan, baik dengan ucapan, tulisan, maupun tingkah laku. Setiap umat Islam berkewajiban melakukan jihad seperti ini, sebab masingmasing individu memiliki potensi yang sama. Dalam pengertiannya yang khusus, jihad al-nafs adalah mencurahkan segenap potensi seseorang dalam berjuang di medan perang. Potensi-potensi yang dapat dimanfaatkan dalam jihad seperti ini, antara lain, kemampuan merakit senjata dan berbagai peralatan perang lainnya, kemampuan mengatur taktik dan strategi berperang, keahlian menembak yang jitu, serta kemampuan menganalisis kekuatan musuh.

\section{Sasaran Jihad}

Jika ditelusuri ayat-ayat Alquran yang berhubungan dengan sasaran jihad, maka ditemukan tiga ayat yang terkait. Satu di antaranya yang termasuk dalam kelompok surah-surah al-makkiyyah, sementara dua ayat lainnya yang termasuk dalam kelompok surah-surah al-madaniyyah. Ayat yang disebutkan berikut ini termasuk dalam kelompok surah-surah al-makkiyyah.

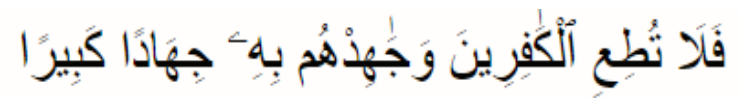

Terjemahnya:

Maka janganlah kamu mengikuti orang-orang kafir, dan berjihadlah terhadap mereka dengan AlQur'an dengan jihad yang besar.

${ }^{17}$ Abi al-Husain Ahmad ibn Faris Ibn Zakariyyah, op. cit., h. 1040.

${ }^{18}$ M. Quraish Shihab, op. cit., h. 506. 
Ayat di atas turun ketika Rasulullah saw. masih berada di Mekah, sehingga orang-orang kafir yang dimaksud adalah orang-orang musyrik yang menolak ajaran Islam. Rasulullah saw. bersama para sahabatnya dilarang mengikuti kehendak orang-orang musyrik yang ingin memaksa beliau mengikuti ajaran mereka. Bahkan, beliau bersama para sahabatnya diperintahkan berjihad dalam menghadapi kemusyrikan mereka.

Pada periode itu, situasi dan kondisi umat Islam masih lemah dan belum memiliki kekuatan fisik, sehingga bentuk jihad yang dilakukan bukan mengangkat senjata, tetapi mencurahkan segala kemampuan menghadapi orang-orang musyrik dengan kalimat yang menyentuh nalar dan kalbu. Menurut M. Quraish Shihab, ayat di atas memerintahkan Rasulullah saw. bersama umat Islam berjihad melawan orang-orang kafir Mekah dengan Alquran. ${ }^{19}$

Dalam menafsirkan ayat di atas, Sayyid Qutub tidak berbicara tentang jihad di medan perang, tetapi justeru menge-tengahkan kisah empat pemuka Quraisy (Abu Jahl, Abu Sufyan, Akhnas ibn Syuraiq, dan Halif ibn Zuhrah), yang masing-masing keluar untuk mencuri dengar Rasulullah membaca Alquran saat beliau sedang salat malam di rumahnya. Keempat tokoh Quraisy tersebut saling memergoki, sehingga mereka saling menasehati agar masing-masing tidak mengulangi perbuatannya yang memalukan itu. ${ }^{20}$

Kehebatan Alquran sebagai media jihad, tidak hanya dari aspek keindahan susunan bahasanya yang membuat pen-dengarnya hanyut, tetapi juga ketidakmampuan penantangnya untuk membuat semisal Alquran. ${ }^{21}$ Sekiranya orang-orang Quraisy mampu meruntuhkan dakwah Rasulullah saw. dengan membuat semacam Alquran, maka pasti mereka tidak perlu mengangkat senjata. Namun, karena tantangan membuat sema-cam Alquran tidak terlayani, maka mereka terpaksa mencari cara lain untuk melawan Rasulullah saw. ${ }^{22}$

Ayat lain yang berbicara tentang sasaran jihad adalah QS. al-Tahrim/66/107: 9 yang berbunyi:

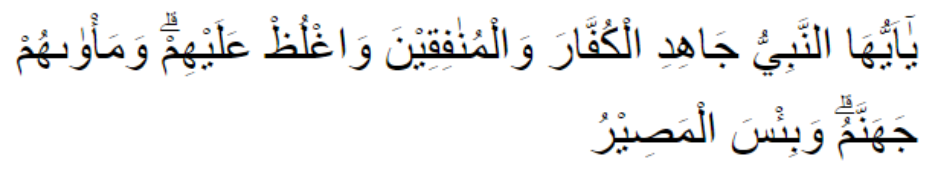

Terjemahnya:

Hai Nabi, perangilah orang-orang kafir dan orang-orang munafik dan bersikap keraslah terhadap mereka. Tempat mereka adalah neraka Jahannam dan itulah seburuk-buruk tempat kembali.

${ }^{19}$ M. Quraish Shihab, Tafsir al-Mishbah: Pesan, Kesan dan Keserasian Al-Qur'an, (Cet. X; Tangerang: Lentera Hati, 2008), h. 496-497.

${ }^{20}$ Sayyid Qutub, Fi Zilal al-Qur'an (Cet. VII; Bairut: Dar Ihya al-Turas \al-'Arabi, 1971), h. 172-173.

${ }^{21}$ Ahmad Syadali dan Ahmad Rofi'I, Ulumul Quran II, (Bandung: CV. Pustaka Setia, 1997), h. 17-18.

${ }^{22}$ M. Quraih Shihab, Mukjizat Al-Quran Ditinjau dari Aspek Kebahasaan, Isyarat Ilmiah dan Pemberitaan Gaib, (Bandung: Mizan, 2003), h. 153-163. 
Selain ayat di atas, ditemukan QS. al-Taubah/9/113: 73 yang redaksinya sama dengan ayat di atas. Dua ayat yang disebutkan terakhir ini masing-masing berada dalam kelompok surah-surah almadaniyyah. Sasaran jihad yang terdapat dalam kedua ayat tersebut tidak hanya tertuju kepada orang-orang kafir, tetapi juga terhadap orang-orang munafik.

Para ulama berbeda pendapat mengenai metode jihad terhadap orang-orang munafik. 'Ali ibn Abi Thalib, yang kemudian didukung oleh Ibn Jarir, mengatakan bahwa orang-orang munafik harus ditaklukkan dengan pedang, sebab mereka merupakan kelompok berbahaya yang bertujuan merusak Islam dari dalam. Sementara itu, Ibn 'Abbas berpendapat bahwa me-reka dihadapi dengan sikap keras dalam bergaul dan menyingkap rahasia mereka di tengah masyarakat umum, sebagaimana yang telah dipraktekkan Rasulullah saw. Al-Qurtubi memilih jalan tengah di antara dua pendapat sebelumnya. Menurutnya, meng-hadapi orang-orang kafir dan orang-orang munafik itu tidak hanya dengan pedang, tetapi juga dengan pelajaran yang baik, dakwah yang baik, atau dengan doa dan seruan. Memerangi kekafiran dan kemunafikan tidak selalu mesti secara keras, sebab terkadang musuh dapat ditundukkan dengan sikap lemah lembut atau hujah yang tepat. ${ }^{23}$

Dalam hal berjihad menghadapi orang-orang kafir, terdapat petunjuk yang diberikan oleh Allah swt. dalam QS. al-Taubah/9/113: 123 sebagai berikut:

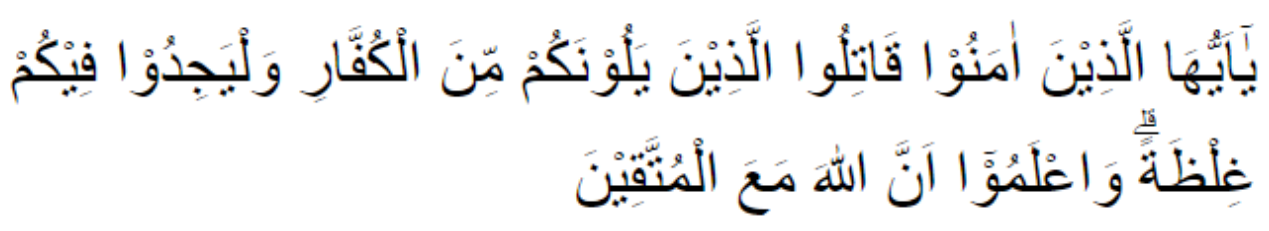

Terjemahnya:

Hai orang-orang yang beriman, perangilah orang-orang kafir yang di sekitar kamu itu, dan hendaklah mereka menemui kekerasan daripadamu, dan Ketahuilah, bahwasanya Allah bersama orang-orang yang bertakwa.

Dalam ayat di atas, Allah swt. memberi dua pedoman dan petunjuk dalam berperang kepada Rasulullah saw. dan kaum muslimin. Pertama, memerangi musuh-musuh Islam yang berada pada lingkaran garis terdekat dengan pusat kedudukan umat Islam, yang kemudian dilanjutkan kepada lingkaran yang lebih jauh. Hal ini bertujuan untuk mengamankan jalannya dakwah Islam dan untuk melindungi keselamatan umat Islam. Musuh-musuh Islam yang terdekat kepada Rasulullah saw. dan umat Islam ketika itu adalah orang-orang kafir yang berasal dari kaum Yahudi yang berdiam di kota Madinah, Khaibar, dan yang memerangi umat Islam di Perang Tabuk. Setelah itu, adalah

${ }^{23}$ Abi Abdillah Muhammad ibn Abi Bakr ibn Farh al-Ansari al-Hazraji Syams al-Din al-Qurtubi, alJami' li Ahkam al-Qur'an, (al-Riyad: Dar 'Alam al-Kutub, 2003) h. 204-205. 
mereka yang berada di daerah Syam, yang ketika itu berada di bawah kekuasaan Romawi Timur yang berpusat di Byzantium. ${ }^{24}$

Kedua, Allah memberikan petunjuk agar kaum muslimin mampu menggunakan kekerasan dan kekuatan kepada orang-orang kafir yang menghalangi dakwah Islam, apabila cara diplomasi dan perlakuan yang lemah lembut dan ramah tamah tidak digubris. Kaum muslimin diperintahkan untuk bersikap adil, kasih sayang, dan ramah tamah kepada orang-orang non-Islam. namun, bila mereka tetap mengganggu kepentingan umat Islam, terutama merintangi dakwah Islam, maka kaum muslimin harus menggunakan kekuatan dan kekuasaan, sehingga mereka menghentikan permusuhan terhadap Islam dan kaum muslimin. ${ }^{25}$

Apabila dalam keadaan terpaksa dan harus ditempuh sikap kekerasan, seyogyanya pasukan Islam meneladani etika perang yang telah dipraktekkan Rasulullah saw. berupa larangan merusak flora dan fauna, tidak membunuh rakyat sipil, tidak merusak fasilitas umum, tidak merusak sarana ibadah, serta tidak membunuh wanita dan anak-anak. Terhadap musuh yang tidak berdaya, tawanan perang, atau sandera, Rasulullah saw. tidak membunuh mereka, bahkan memberi bantuan pengobatan. ${ }^{26}$ Dengan demikian, aksi yang dilakukan berupa bom bunuh diri yang diledakkan di tengah-tengah masyarakat umum, seperti di Hotel JW Marriott dan Ritz-Carlton ${ }^{27}$, apalagi di tempat ibadah, seperti yang terjadi di Masjid Markas Kepolisian Resort Kota Cirebon, ${ }^{28}$ merupakan perbuatan keji yang melanggar etika perang dalam Islam. Perbuatan seperti itu tidak dikatagorikan sebagai jihad dan pelakunya tidak disebut sebagai mujahid.

\section{Implikasi Jihad}

Telaah menyangkut implikasi jihad, dapat ditemukan pada beberapa ayat, di antaranya adalah QS al-'Ankabut/29/85: 69 sebagai berikut:

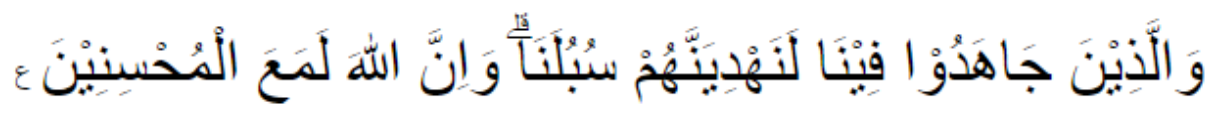

Terjemahnya:

${ }^{24}$ Departemen Agama RI., Al-Qur'an dan Tafsirnya, (Cet. III; Jakarta: Departemen Agama RI, 2009), h. 235-236.

25Ibid., h. 236-237.

${ }^{26}$ Altaf Gaufar, The Challenge of Islam, terj. Anas Mahyuddin, Tantangan Islam, (Cet. III; Bandung: Pustaka, 1982), h., 230.

27Wedhaswary, Inggried Dwi. Pelaku Bom Bunuh Diri Marriott Remaja 18 Tahun, dalam http://female.kompas.com/read/2009/08/08 /18180192/pelaku.bom. bunuh. diri.marriott. remaja. 18.tahun, diakses pada 28 Juni 2011.

${ }^{28}$ Metrotvnews.com, Bom Bunuh Diri di Masjid Polresta Cirebon, Puluhan Terluka, dalam http://metrotvnews.com/read/newsvideo/2011 /04/15/126356/Bom-Bunuh-Diri-di Masjid-PolrestaCirebon-Puluhan-Terluka, diakses pada 28 Juni 2011. 
Dan orang-orang yang berjihad untuk (mencari keridhaan) Kami, benar-benar akan Kami tunjukkan kepada mereka jalan-jalan Kami. Dan sesungguhnya Allah benar-benar beserta orangorang yang berbuat baik.

Dalam ayat di atas, frasa la nahdiyannahum subulana sangat relevan dengan pembahasan ini. Penggunaan bentuk plural pada kata subulana, menunjukkan bahwa orang-orang yang berjihad atas nama Allah, akan mendapat petunjuk dalam melewati berbagai jalan yang diridhai oleh Allah. Jika dihubungkan dengan makna kata subulana yang berakar pada huruf sin, ba, dan lam, yang bermakna asal "mengirim sesuatu dari ketinggian ke bawah", ${ }^{29}$ maka dapat dipahami bahwa petunjuk dari Allah akan mengalir secara kontinu kepada orang-orang yang berjihad, sehingga mereka tidak akan menempuh jalan yang sesat.

Ayat di atas juga mengandung makna bahwa ruang lingkup dan lapangan jihad sangat luas, bisa dilaksanakan dengan berbagai cara, baik berupa perkataan, tulisan, dan pada situasi tertentu dapat dilakukan dengan senjata. Karena luas dan banyaknya lapangan jihad, maka banyak sekali jalan yang dapat ditempuh seorang mukmin untuk sampai kepada ridha Allah, asal semua jalan yang ditempuhnya itu diniatkan untuk menegakkan kebenaran, keadilan, dan kebaikan. ${ }^{30}$

Dengan demikian, ayat di atas menegaskan bahwa orang yang mengerahkan kemampuannya dan secara bersungguh-sungguh dalam melaksanakan perintah Allah, termasuk di antaranya adalah menuntut ilmu dan berbuat baik kepada sesamanya, maka Allah akan mengantarnya ke aneka jalan kedamaian dan kebahagiaan, baik di dunia maupun di akhirat.

Ayat lainnya yang berkenaan dengan implikasi jihad adalah QS al-Baqarah/2/87: 218 sebagai berikut:

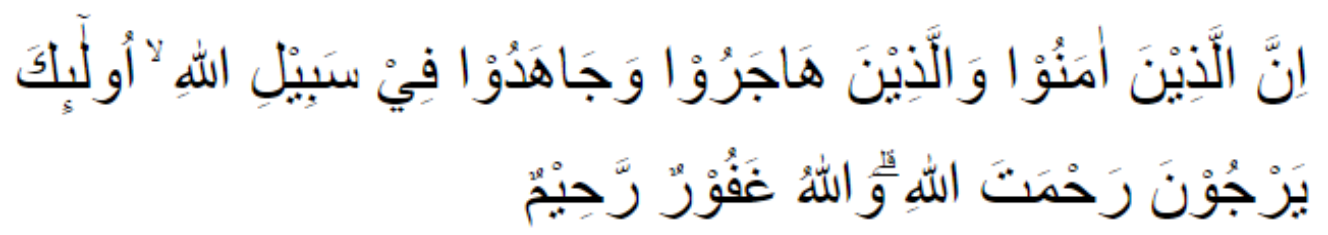

Terjemahnya:

Sesungguhnya orang-orang yang beriman, orang-orang yang berhijrah dan berjihad di jalan Allah, mereka itu mengharapkan rahmat Allah, dan Allah Maha Pengampun lagi Maha Penyayang.

Kata rahmat dalam ayat di atas, berakar pada huruf ra, ha, dan mim, yang bermakna dasar "kelembutan, kebaikan, dan kasih sayang". ${ }^{31}$ Dengan demikian, kriteria mendapatkan kelembutan dan kasih sayang dari Allah adalah dengan beriman, berhijrah, dan berjihad di jalan Allah. Selain itu, Allah akan mengampuni dosa-dosa yang telah diperbuat orang tersebut.

\footnotetext{
${ }^{29}$ Abi al-H\{usain Ahmad ibn Faris Ibn Zakariyya, op. cit., h. 504.

${ }^{30}$ Departemen Agama RI, op. cit., h. 451-452.

${ }^{31} \mathrm{Abi}$ al-Husain Ahmad ibn Faris Ibn Zakariyya, op. cit., h. 446.
} 
Menurut al-Maragi, orang-orang yang tergolong dalam ayat di atas adalah Rasulullah saw. dan para sahabatnya. Mereka mendapat rahmat dan ampunan dari Allah, sebab mereka berhijrah dari Mekah ke Madinah, yang kemudian menyusun kekuatan untuk menaklukkan kota Mekah. ${ }^{32}$ Titik berat Hamka dalam ayat di atas, tampaknya tertuju kepada tingkat penyempurnaan iman kepada Allah. Menurutnya, ada tiga kriteria seseorang untuk disebut sebagai mukmin sejati: (1) orang yang memiliki keimanan yang teguh, (2) ikut berhijrah, dan (3) ikut berjihad jika datang perintah. Orang-orang yang memiliki kriteria ini akan mendapatkan rahmat dan ampunan dari Allah. ${ }^{33}$

Dari penjelasan di atas, dapat dipahami bahwa salah satu di antara implikasi jihad adalah mendapatkan kasih sayang dan ampunan dari Allah. Dalam konteks kehidupan duniawi, para mujāhid akan mendapatkan kasih sayang berupa rezeki yang berlimpah dan kemudahan dalam beraktivitas. Sementara itu, di akhirat akan memperoleh ampunan dan kasih sayang di surga.

QS. al-Anfal/8/88: 74 semakin memperjelas tentang pemberian rezeki berlimpah dari Allah bagi orang yang berjihad.

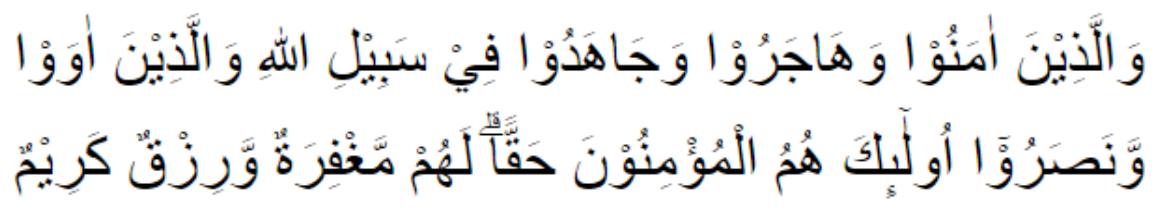

Terjemahnya:

Dan orang-orang beriman dan berhijrah serta berjihad pada jalan Allah, dan orang-orang yang memberi tempat kediaman dan mem-beri pertolongan (kepada orang-orang muhajirin), mereka itulah orang-orang yang benar-benar beriman. Mereka memperoleh ampun-an dan rezeki (ni'mat) yang mulia.

Klausa terakhir dari ayat di atas menegaskan bahwa orang-orang yang berjihad di jalan Allah akan mendapatkan ampunan dan rezeki yang mulia. Dalam klausa ini terdapat dua kata kunci, yaitu magfirah dan rizq. Kata magfirah berakar pada huruf gain, fa, dan ra yang memiliki arti asal "tabir/penutup", sehingga pada hakikatnya kata magfirah berarti "dosanya tertutup". ${ }^{34}$ Dengan demikian, orang-orang yang berjihad di jalan Allah akan terhapus dosanya, karena mendapat ampunan dari Allah swt.

Adapun kata rizq, tersusun dari huruf ra, zai, dan qaf yang memiliki arti asal "pemberian yang terkait dengan waktu". ${ }^{35}$ Arti ini menunjukkan bahwa rezeki merupakan pemberian Allah yang diberikan kepada manusia melalui hasil usahanya, baik di waktu siang maupun malam. Oleh karena jihad merupakan usaha keras dan sungguh-sungguh dalam menegakkan ajaran Islam, maka sangat wajar jika Allah memberi balasan dengan rezeki yang berlimpah bagi pelakunya.

\footnotetext{
${ }^{32}$ Ahmad Mustafa Al-Maragi, op. cit. h. 137.

${ }^{33}$ Hamka, op. cit., h. 254.

${ }^{34} \mathrm{Abi}$ al-Husain Ahmad ibn Faris Ibn Zakariyya, op. cit., h. 801.

${ }^{35}$ Ibid., h. 401.
} 
Menurut Sayyid Qutub, disebutkannya rezeki dalam ayat di atas, karena sangat sesuai dengan jihad (perjuangan), infak, pemberian perlindungan, pemberian per-tolongan, dan beban-beban tugas lainnya yang diemban para mujahid selama ini. Di samping itu, mereka akan mendapat pengampunan sebagai salah satu bentuk rezeki yang termulia. Rezeki yang diperoleh para pejuang tersebut, akan didapatkan di dunia dan di akhirat. Di dunia akan memperoleh penghargaan sesuai dengan hasil perjuangannya, termasuk harta rampasan bagi mereka yang memperoleh kemenangan di medan perang. Sementara itu, di akhirat akan mendapatkan kenikmatan di dalam surga, dan itulah rezeki termulia yang diterima dari Allah swt. ${ }^{36}$

QS. Ali 'Imran/3/89: 142 semakin memperjelas eksistensi surga sebagai implikasi jihad.

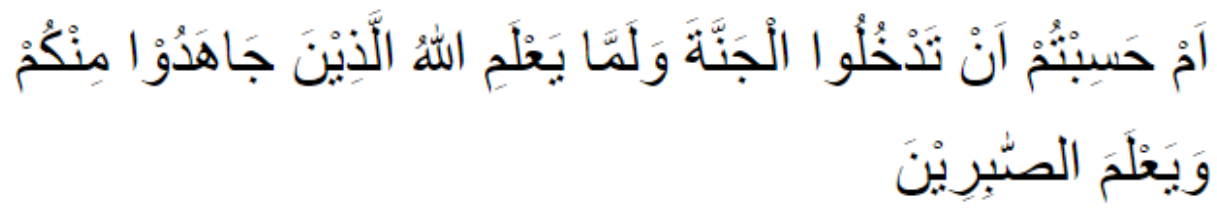

Terjemahnya:

Apakah kamu mengira bahwa kamu akan masuk surga, padahal belum nyata bagi Allah orangorang yang berjihad di antaramu, dan belum nyata orang-orang sabar.

Ayat di atas merupakan koreksi dan celaan Allah terhadap sikap sebagian umat Islam dalam peristiwa perang Uhud. Pada awalnya mereka ingin berperang dengan semangat berapi-api, bahkan mereka mendorong Rasulullah saw. agar keluar kota untuk memerangi pihak Quraisy dan jangan hanya bertahan di Kota Madinah. Mereka dengan tegas sanggup berbuat segala sesuatu untuk menghadapi musuh, meski mereka akan mati seperti para pahlawan di Badar. Namun, ternyata mereka kehilangan semangat setelah berada dalam suasana yang terjepit dan gawat, bahkan mereka melanggar terhadap apa yang telah disepakati bersama Rasulullah saw.. ${ }^{37}$

Frasa am hasibtum di awal ayat adalah nahi (larangan) yang dikemukakan dalam bentuk istifham (pertanyaan) dan sebagai pencela terhadap sikap sebagian umat Islam yang kehilangan semangat dalam perang Uhud. Dengan demikian, maksud sebenarnya ayat itu adalah jangan kalian beranggapan bisa masuk surga, sedang kalian tidak bersungguh-sungguh mempertaruhkan nyawa di medan perang. ${ }^{38}$ Surga yang begitu tinggi dan mulia, sangat mahal harganya, dan tidak dapat dibeli hanya dengan ungkapan di mulut. Akan tetapi, surga meminta kesungguhan, semangat, antusias, kesabaran, pengorbanan, dan kerja keras. ${ }^{39}$

Surga yang dimaksud dalam konteks ayat di atas adalah sebuah tempat kenikmatan yang disediakan bagi orang-orang mukmin yang berperang di jalan Allah dengan jiwa dan hartanya, sebagaimana yang dipertegas dalam QS. al-Taubah/9/113: 111. Gambaran kenikmatan surga disebutkan dalam QS al-Ra'd/13/96: 35, yakni mengalir sungai-sungai di dalamnya, buahnya tak terhenti, dan naungannya sangat sejuk.

\footnotetext{
${ }^{36}$ Sayyid Qutub, op. cit., h. 74.

${ }^{37}$ Departemen Agama RI, op. cit., h. 53.

${ }^{38}$ Ahmad Mustafa al-Maragi, op. cit. h. 84.

${ }^{39}$ Hamka, op. cit., 101-102.
} 


\section{Penutup}

Jihad adalah pengarahan maksimal seluruh daya upaya seseorang secara bersungguh-sungguh untuk menghancurkan dan mencegah timbulnya bentuk kesesatan, kemungkaran, atau ke-maksiatan oleh musuh-musuh yang berwujud manusia-manusia ingkar, setan yang menyesatkan, atau hawa nafsu. Bentuk-bentuk jihad dapat dibedakan atas jihad amwal (harta) dan anfus (jiwa). Jihad amwal dapat dilakukan dalam bentuk menyumbangkan harta benda untuk membantu fakir-miskin, membangun mesjid, sekolah, rumah sakit, atau menyiapkan lapangan kerja, atau mem-bantu pengadaan alat-alat perang, atau memberi tunjangan kepada kerabat dan keluarga para mujahidin. Sementara itu, jihad anfus dapat dilakukan dalam bentuk pemanfaatan potensi lisan dan tulisan dalam membela ajaran Islam, atau membantu merakit senjata dan mengatur strategi perang, atau terjun langsung berlaga di medan perang.

Implikasi jihad sangat terkait dengan kehidupan dunia dan akhirat. Dalam kehidupan duniawi, para mujahid akan senantiasa mendapat petunjuk dari Allah untuk menempuh jalan yang lurus, sehingga tidak ada kekhawatiran akan melewati jalan yang sesat. Selain itu, mereka mendapat imbalan yang setimpal, derajat yang tinggi, dan keberuntungan, seperti penghargaan, pengakuan, kekuasaan, kebahagiaan, kedamaian, dan rezeki yang melimpah. Sementara itu, di akhirat nanti, mereka akan mendapatkan am-punan, kasih sayang, dan pahala yang besar dari Allah. Atas dasar itulah sehingga mereka disebut sebagai orang-orang yang beruntung, sebab mereka menempati posisi yang tinggi di surga.

\section{Daftar Rujukan}

Abu Zahrah, Muhammad. Usul al-Fiqh. Al-Qahirah: Dar al-Fikr al-‘Arabi, t.th..

Benarkah Islam disebarkan dengan Pedang, dalam http:/ /matabaca. multiply. com/journal/item/6, diunduh pada tanggal 13 Juni 2010.

Departemen Agama RI. Al-Qur'an dan Tafsirnya. Cet. III; Jakarta: Departemen Agama RI, 2009. Al-Qur'an dan Terjemahnya. Jakarta: Proyek Pengadaan Kitab Suci al-Qur'an, 1984/1985.

Al-Dimasyqi, Abu al-Fida' Isma'il ibn 'Umar ibn Kasir al-Qurasyi. Tafsir al-Qur'an al-'Azim, dalam Program CD al-Maktabah al-Syamilah, versi 2.11, http://www. shamela.ws.

Drama Perempuan Pelaku Bom Bunuh Diri di Palestina, dalam http://www. bloggaul.com/bubu_okky/readblog/87246/ drama-perempuan-pelaku-bom-bunuh-diri-dipalestina, diakses pada tanggal 13 Juni 2010.

Gaufar, Altaf. The Challenge of Islam, terj. Anas Mahyuddin, Tantangan Islam. Cet. III; Bandung: Pustaka, 1982. 
Hamka. Tafsir al-Azhar. Cet. III; Jakarta: Panji Masyarakat, 1982.

Ibn Zakariyya, Abi al-Husain Ahmad ibn Faris. Mu'jam al-Maqayis fi al-Lugah. Cet. II; Barut: Dar al-Fikr li al-Taba'ah wa al-Nasyr wa al-Tauzi', 1998.

Al-Juzbat, Mahmud ibn Ibrahim. Al-Durrah al-Gurra' fi Nasihat al-Salatin wa al-Qudat wa alUmara'. Al-Riyad: Maktabah Nazar Mustafa al-Baz, 1996.

Kazhim, Musa dan Alfian Hamzah. Fitnah Fitna. Cet. I; Hikmah, 2008.

Al-Mawardi, Abu al-Hasan 'Ali ibn Muhammad ibn Muhammad ibn Habib al-Basri al-Bagdadi alNukat wa al-'Uyun, dalam Program CD al-Maktabah al-Syamilah, versi 2.11, http:// www.shamela.ws.

Al-Magribi, Taqiy al-Din al-Hilali. Al-Hadyah al-Hidayah ila al-Ta'ifah al-Tijaniyyah, dalam Program al-Maktabah al-Syamilah, versi 3.5, http://www.shamela.ws.

Al-Maragi, Ahmad Mustafa. Tafsir al-Maragi. Bairut: Dar al-Fikr li al-Taba'ah wa al-Nasyr wa alTauzi', t.th.

Mattola, M. Galib. Jihad, dalam http://www.psq.or.id/ ensiklopedia.detail.asp?mnid=34\&id=60, diunduh pada tanggal 31 Oktober 2009.

Metrotvnews.com, Bom Bunuh Diri di Masjid Polresta Cirebon, Puluhan Terluka, dalam http://metrotvnews.com/read/ newsvideo/2011/04/15/ 126356/Bom-Bunuh-Diri-di-MasjidPolresta-Cirebon-Puluhan-Terluka, diakses pada 28 Juni 2011.

Al-Mișri, Muḥammad ibn Mukarram ibn Manzur al-Afriqi. Lisan al-'Arab. Cet. I; Bairut: Dar Sadir, t.th.

Moleong, Lexy J. Metodologi Penelitian Kualitatif. Cet. X; Bandung: PT Remaja Rosdakarya, 1999.

Palestina: Bom Bunuh Diri, Balasan atas Pembantaian Israel, dalam http://www.gatra.com/200205-14/artikel.php?id=17595, diakses pada tanggal 13 Juni 2010.

Al-Qasimi, Syaikh Zafir. Al-Jihad wa al-Huquq al-Dauliyyah al-Ammah fi al-Islam. Bairu: Dar al'Ilm li al-Malayin, 1986.

Al-Qardawi, Yusuf. Al-Ijtihad fi al-Syari'ah al-Islamiyyah ma'a Nazarat Taḥliliyyah fi al-Ijtihad al-Mu'asir, terj. Ahmad Syathori, Ijtihad dalam Syari'at Islam: Analisis terhadap Ijtihad Kontemporer. Cet. I: Jakarta: Bulan Bintang, 1987.

Al-Qurtubi, Abi Abdillah Muhammad ibn Abi Bakr ibn Farh al-Ansari al-Hazraji Syams al-Din. Al-Jami' li Ahkam al-Qur'an. Al-Riyad: Dar 'Alam al-Kutub, 2003.

Qutub, Sayyid. Fi Zilal al-Qur'an. Cet. VII; Bairut: Dar Ihya al-Turas al-‘Arabi, 1971. 
Al-Razi, Muhammad ibn Abi Bakr ibn 'Abd al-Qadir. Mukhtar al-Sihhah. Bairut: Maktabah Lubnan Nasyirun, 1995.

Shihab, M. Quraish. Dia Dimana-mana: “Tangan” Tuhan di Balik Setiap Fenomena. Cet. V; Tangerang: Lentera Hati, 2007.

-------. Mukjizat Al-Quran Ditinjau dari Aspek Kebahasaan, Isyarat Ilmiah dan Pemberitaan Gaib. Bandung: Mizan, 2003.

-------. Tafsir al-Mishbāh: Pesan, Kesan dan Keserasian Al-Qur'an. Cet. X; Tangerang: Lentera Hati, 2008.

-------. Wawasan al-Qur'an: Tafsir Maudhu'i atas Pelbagai Persoalan Umat. Cet. IX; Bandung: Penerbit Mizan, 2007.

Shihab, Umar. Hukum Islam dan Transformasi Pemikiran. Cet. I; Semarang: Dina Utama, t.th.

Syadali, Ahmad dan Ahmad Rofi'i. Ulumul Quran II. Bandung: CV. Pustaka Setia, 1997.

Takruri, Nawwaf. Al-Jihad bi al-Mal fi Sabilillah, terj. Asep Sobari dan Henri Shalahuddin, Dahsyatnya Jihad Harta. Cet. I; Jakarta: Gema Insani Press, 2007.

Terorisme di Indonesia, dalam http://id.wikipedia.org/wiki/ Teror-isme di Indonesia, diunduh pada tanggal 11 Juni 2010.

Wedhaswary, Inggried Dwi. Pelaku Bom Bunuh Diri Marriott Remaja 18 Tahun, dalamhttp://female.kompas.com/read/ 2009/08/08/18180192/pelaku.bom. bunuh.diri.marriott. remaja.18.tahun, diakses pada 28 Juni 2011.

Widodo, L. Amin. Fiqih Siyasah dalam Hubungan Internasional. Cet. I; Yogyakarta: PT Tiara Wacana Yogya, 1994. 